\title{
Article
}

\section{Rethinking the China-Israel BIT in Light of the Fragmented International Investment Legal Order: A Commentary}

\author{
Hadas Peled*
}

The practice of International Investment Agreements (IIAs) has developed immensly during the past 15 years. In particular, China has gained significant experience in concluding IIAs, adapting to concerns raised following an overflow of investor state disputes. This article analyzes an interesting case-study: an investment promotion agreement signed and negotiated between China and Israel (CIBIT) during the 1990s, however ratified more than a decade later, in 2009, without modifying or updating its contents. This commentary identifies major gaps in the CIBIT, including those concerning its preamble, key definitions of 'Investment' and 'Investor', standard of protection: FET, MFN, NT, and ISDS provisions, vis-à-vis the wider transformation of international investment law. Special emphasis is given to China's change in approach to investment and IIAs. The growing economic ties between China and Israel, including recent discussions about a free trade agreement, requires a thorough understanding of the risks and benefits of the CIBIT. Therefore, the commentary concludes with an outline of a strategic roadmap for the future revision of the CIBIT.

Keywords: International Investment Agreements, China and Israel FDI Policies, MFN, NT, Investor State Dispute Resolution (ISDS), FET, ICSID.

* Ph.D. candidate at Tsinghua University School of Law; Adjunct Lecturer at Bar Ilan University, Israel; Attorney-at-Law (Israel Bar). LL.B. (Hebrew Univ. of Jerusalem), LL.M. (Tsinghua). ORCID: http://orcid.org/0000-0002-1754-7622. The author may be contacted at: hadas12@yahoo. com / Address: Tsinghua University Law School, Haidian District, Beijing 100084 P.R. China. 


\title{
I. INTRODUCTION
}

\section{A. The Fragmented Practice of International Investment Agreements and the CIBIT}

International investment law is fundamentaly fragmented. So far, attempts to conclude an international investment agreement with an all-encompassing scope of application have been futile. ${ }^{1}$ It is similar to the World Trade Organization ("WTO")'s single undertaking. This fragmentation is exacerbated by fundamental criticism concerning the effectiveness of international investment agreements ("IIA"). In recent years, there has been a reinvigoration of the academic discourse on the causal link between IIAs and the promotion of foreign direct investment ("FDI"). The themes explored the impact of IIAs on FDI, generally showing mixed results. FDI had flown to countries that did not conclude IIAs, Brazil being one such example. ${ }^{2}$ In the case of China, Professor An Chen concluded:

\begin{abstract}
Frankly, the main reason for the huge inflow of FDI into China over the past two decades-odd is not the conclusion of Sino-foreign BITs giving complete jurisdiction to ICSID, but the cheap labor, the preferential policies to foreign investment, the vast domestic markets, and comparatively rich and low-price resources in China.
\end{abstract}

IIAs signal states' willingness to receive investments, but simultaneously impose asymmetric obligations on those states. ${ }^{4}$ Increasing investor-state litigation during the past decade, ${ }^{5}$ with landmark cases challenging governmental acts such as the Plain Packaging Cigarettes Policy, attracted increasing criticism. ${ }^{6}$ There are also controversies concerning the legitimacy of such claims in wake of government intervention in times of financial crises. ${ }^{7}$ Arbitrators are required to draw the line between legitimate governmental acts under the state power doctrine, and between illegitimate acts that call for international intervention. ${ }^{8}$

Recent trends of IIA negotiations are all trying to address these concerns with tailor-made solutions, without attempting to resolve the basic element of fragmentism. The China-Canada BIT, ${ }^{9}$ China-Australia FTA, ${ }^{10}$ and the TPP $^{11}$ all address such concerns with different solutions. Going back to the 1980s and the 1990s, influenced by the Washington Consensus on benefits of privatization and rule of law, IIA programs were increasing. ${ }^{12}$ Many of these IIAs were drafted 
using broad and vague language, leaving key issues unresolved, as shall be demonstrated below in this case study. Many states have already been upgrading their BITs or FTAs to fit the current informed approach. ${ }^{13}$ E.g., the China-ASEAN FTA which was only concluded in 2009, was upgraded in 2015 in order to address recent challenges. ${ }^{14}$ The trend of upgrading existing IIAs is likely to continue in the coming years.

Against this backdrop, we now turn to review the case study chosen, namely, the China-Israel BIT ("CIBIT"), ${ }^{15}$ coupled with a short necessary historical exposition about its conclusion and ratification. The modern states of China and Israel were established following the Second World War. Upon establishment, both were influenced by social-Marxist theories, but did not establish bilateral diplomatic or economic relations soon. During the 1960's, in line with China's growing isolation in the international arena, the relationship between the two countries showed a long period of stagnation. ${ }^{16}$ With the beginning of the reform era in China, relations gradually developed starting with economic cooperation and technical assistance, substantially on the part of Israel. During the period of the late 1970s and early 1980s, both governments initiated promoting scientific and technical support by Israeli experts. ${ }^{17}$ Such cooperation stretched even to the provision of technical assistance in the modernization of defense related services. Delegates of both Parties opened representative offices which permitted holders of Chinese and Israeli passports to travel to the other side as of 1987. Ultimately, full diplomatic relations were officially established in January $1992 .{ }^{18}$ This was inseparable from the two countries' efforts to enhance their status in the international arena. For China, this trend was consistent with its efforts to build a comprehensive international network of bilateral relations, securing its international status. ${ }^{19}$ While for Israel, the efforts echoed various political and economic concerns, mostly dealing with a boycott led by Arab countries. ${ }^{20}$

Following the formal establishment of diplomatic relations, economic ties between the parties gradually expanded. The formal legal relationship was expanding and the CIBIT is only an example of this larger process. The CIBIT was initially negotiated following the establishment of diplomatic relations, whose form was concluded and signed in 1995. The CIBIT was designed to strengthen the foundation of economic links between the two nations and to encourage investment. However, this trend was somewhat hindered by a cancellation on the part of Israel 
of a deal for the sale of the Phalcon airborne security system in the early 2000s. Although the form of the CIBIT was agreed by the parties several years earlier, it was neither ratified, nor entered into force by any party.

The global economic crisis that showed its severe effects in 2007-2008 provided a new neutral platform for the strengthening of cooperation between China and Israel. The economies of both countries were only moderately affected by this crisis. ${ }^{21}$ This provided a good foundation for cooperation, further mutually recognizing the importance of their relationship. This period saw the conclusion of various agreements and protocols. As part of this trend, the CIBIT was finally ratified and entered into force in January 2009. Interestingly, and not withstanding clear trends of IIAs available at the time of the ratification, the contents of the CIBIT, negotiated and agreed to more than a decade earlier, were not updated.

The lengthy process, with its 'ups' and 'downs,' created a significant time gap between the negotiation and conclusion phase and the ultimate ratification phase. According to a Joint Feasibility Report made in 2014, there are future positive prospects for growing economic and investment ties. Therefore, the question discussed in this commentary, i.e., the suitability of the CIBIT to current IIA practices is extremely relevant and of high importance.

\section{B. Outline}

This article is divided into four parts including Introduction and Conclusion. Part two will discuss the underlying policy considerations towards the investment of each party and identify the key trends affecting the development and practice of IIAs, with a view that the text of an IIA should be understood in its broader functional context. Against this backdrop, Part three will analyze the key provisions of the CIBIT and discuss its fundamental gaps, focusing on its terms, purposes, main definitions, standards of protection, and dispute resolution mechanism. The analysis takes a comparative perspective, taking into account the tribunals' approach to such provisions, and comparing China's approach in its recent IIAs. The emphasis on China's approach is made in light of its growing role and dominance as an international investor, and in light of its active approach in concluding IIAs. Lastly, Part four, building on recent trends and approaches of IIAs, will suggest and discuss possible avenues for the amendment of the CIBIT. 


\section{The Evolution of the Parties' Investment Strategies AND Considerations}

Overall, Israel appears more 'friendly' or conducive to investment, compared to China. $^{22}$ At the same time, China has been changing its paradigm towards inward and outward investments, as discussed below.

\section{A. China's Investment Strategy and Policy Considerations}

China's investment strategy and policy considerations have evolved dramatically over the past thirty years. This process reflects the immense changes that the Chinese economy and legal environment have undergone during this time. The underlying philosophy behind the Chinese economic and investment regime is based on the "Five Principles of Peaceful Co-Existence.", This dominant doctrine, in the field of FDI, was processed and developed to the so called "three guiding principles of international economic cooperation and exchange," ${ }^{24}$ which comprise the principles of sovereignty, equality, and mutual benefit with reference to international practice. At the beginning of the reform era, Chinese efforts focused on attracting investment of any kind (although preferably with added-value involving advanced technology transfer). Generally, China's policy considerations for the early stage of economic development was more of a capital/investment importing country. Now, following three and a half decades of growth and development, with considerable foreign reserves, Chinese policy consideration is equally focused on import/export of capital and investment. ${ }^{25}$

The starting point of a modern FDI regime arrived in China in 1978, when Deng Xiaoping officially launched the "open door policy." It opened a restricted gate for foreign investment, in form, scope, and geographic breadth. This was consistent with Deng Xiaoping's underlying philosophy of gradual reform based on trial and experience ("feeling the stones while crossing the river" 摸着 石头过河). The government, heavily dominant in China's economic activities, closely monitored and influenced the pace and direction of FDI. The Chinese government played an overwhelming role both with the approval of projects and investments, and in many cases, as a partner through its central or local level owned corporations. ${ }^{26}$ Generally, FDI was directed and permitted in areas that could promote the development of China. However, detailed criteria to screen 
such projects was not implemented during the 1980's. In 1995, the national foreign investment catalogue, classifying projects as either prohibited, restricted or encouraged, was promulgated, clarifying the scope of investments and their priorities. The Chinese government granted out-reaching preferential tax treatment to foreign invested enterprises, providing them with favorable taxation policies compared to those provided to local Chinese enterprises. ${ }^{27}$ Moreover, competition driven by the different provinces to attract foreign investment has led to the provision of even more far-reaching investment incentives, especially for $R \& D$ and technology projects. ${ }^{28}$ The global economic crisis in 2007, as well as the change of focus from a strict capital import to capital export orientation, led the Chinese central government to reform and phase-out these out-reaching taxation incentives. ${ }^{29}$ Nonetheless, local policies by the different localities may still offer exemptions and incentives to innovative foreign investments. ${ }^{30}$

Chinese government is such highly dominant in the economy that it could apply to FDI, as well. As of the beginning of the reform era, in order to assure that investment is made in encouraged fields suitable for the level of opening up of the economy, China established an extensive monitoring array. The foreign investment approval process involves different governmental authorities, mainly the Ministry of Commerce ("MOFCOM"), the State Administration of Industry and Commerce ("SAIC"), the National Development and Reform Commission ("NDRC"), and the State Administration of Foreign Exchange ("SAFE"). These ministries and bureaus are required to provide their approvals as a pre-condition prior to the actual investment. The level of offices involved is determined by the scope of the proposed investment, from local to provincial, and up to state levels and relevant ministries. ${ }^{31}$ Such approvals are required to allow the transfer of funds from and to China, under SAFE's controlling scrutiny.

At the same time, a separate world of corporate governance was created to support such policy targets authorized by the central government, tagging the different type of foreign greenfield investments as Foreign Investment Enterprises ("FIEs"). FIEs were prescribed under numerous specialized regulations that developed over the years, governing their formation and management. The key structures of such greenfield investments are Equity Joint Venture ("EJV"), Contractual Joint Venture ("CJV"), ${ }^{33}$ Wholly Foreign Owned Enterprises ("WFOE"), and Foreign Invested Companies Limited by Shares ("FICLS"). 
They became familiar to foreign players who wanted to invest in China. Thus, the outcome was the creation of a separate regime, rather than a unified one, which applied solely to the creation and management of foreign investments. ${ }^{36}$

Thus, during the first three decades of reform the general underlying strategy of the Chinese government with regard to FDI was contrary to the concept of national treatment ("NT"). China created a separate governing regime and corporate governance, which applies to foreign players but not to domestic ones, with cherry tax benefits that were supposed to lure investors to China. The resulting uneven playing-field was criticized both by foreign players that were required to deal with long red-tape processes, and by local Chinese players that were not entitled to enjoy the tax benefits. This was evident in China's IIAs practice, as China hesitated and did not include NT obligations in most of the IIAs it has concluded. As shown below, this is one of the features of the CIBIT.

China's accession to the WTO in 2001, coupled with the 'WTO+ commitments' for greater transparency, gradually led to a change in this predominated counter NT approach. The global economic crisis in 2007 and the growing role of the private economy compared to state economy, were also important factors in this process. Under Xi Jinping's regime, the Chinese bureaucracy is increasingly developing and devising new strategies and policies for FDI. At the project approval level, a reform relaxing the pre-establishment approval process for projects was introduced by the NDRC, limiting the pre-approval process only to specialized projects, rather than any type of project. At the same time, specialized free trade zones ("FTZs") were created, "cutting the red-tape" for businesses whose activities do not fall within a specified list (hereinafter Negative List). The FTZs allow incorporation and reporting in accordance with the Company Law, suspending the implementation of various specialized restrictive laws and formations as discussed above.

Additionally, this concept of NT lies in the foundation of the Draft Foreign Investment Law. In early 2015, MOFCOM published a notice for comments with a detailed proposed draft law concerning inward foreign investment in China. ${ }^{37}$ This draft has been presented by MOFCOM for comments and is expected to undergo further deliberation. However, it is a highly significant message from China about its intentions and goals in further reforming the legal system regarding FDI. In principle, the draft suggests that the Foreign Investment Law will reshape 
the landscape for all FIEs in China from an entity structure perspective, and, at least in theory, will put FIEs on the same playing field as domestic entities, in terms of structure and applicable laws.

Another notable development, with the expansion of the Chinese economy is that more transactions are directed at existing Chinese businesses in cross border merger and acquisitions ("M\&A") rather than greenfield investments. This created another type of approval process specialized for M\&A, subjecting them both to anti-monopoly review and to national security review. Anti-monopoly review is conducted in accordance with the Anti-Monopoly Law ("AML") and is required when a certain transaction meets the thresholds set out in the regulations. ${ }^{38}$ The AML allows MOFCOM, the supervising authority, to apply a multitude of competition and non-competition considerations, including protection of fair market competition; enhancement of economic efficiency; promotion of consumer welfare, the safeguard of social public interest; and the promotion of the healthy development of the socialist market economy. Moreover, industrial policy considerations are permitted including the promotion and formation of national champions. Consequently, it may be argued that an underlying counter NT approach still lies in the foundation of the Chinese government's policy and actions. $^{39}$

On that account, a "National Security Review" was introduced by the Chinese State Council in 2011. The National Security Review is required when foreign investors are considering acquiring stakes in a military-related enterprise or in enterprises which may affect national economic security, such as major agricultural producers, major energy and resources, infrastructure, transport, and key technologies. This review mechanism evaluates the impact of any proposed acquisition by foreign investors of a domestic enterprise on: (1) national defense and security including on the domestic capability to produce products or provide services; (2) relevant facilities necessary for national defense and a stable operation of the national economy; (3) public order; and (4) R\&D capacity related to key technologies needed for national security. ${ }^{40} \mathrm{MOFCOM}$ has the oversight to approve or reject such a transaction. The Draft Foreign Investment Law expands the concept of 'national security' introduced initially in the AML with a detailed mechanism for its implementation. This was supplemented by provisional regulations applicable in FTZs concerning the application of a national security 
review in an attempt to streamline this process. ${ }^{41}$ Thus, the shift in orientation towards NT is more predominant in the post establishment procedure rather than the pre-establishment procedure. Under the concept of "Social Market Economy with Chinese Characteristics," the Chinese government will rather continue to have a broad scope of discretion and a dominant role. ${ }^{42}$

The discussion about Chinese strategy towards FDI cannot be complete without addressing China's outward investment strategy. In the aftermath of the 2007 global economic crisis, China began shifting its focus towards outward investment. From emphasized inward investment the focus has shifted to a more balanced policy encouraging Chinese enterprises to 'go global' and invest internationally. The "One Belt, One Road" initiative, through economic cooperation, particularly serves as a roadmap for such strategic plans. ${ }^{43}$ This strategy was implemented and incorporated into the 13th Five Year Plan for balancing outward and inward capital flows. With an overall tendency of devaluation of approval authorities, the Chinese government is continually simplifying the approval process of outward investment projects. Major state-owned enterprises are allowed to file their overseas investments without having to submit them for preliminary examination and approval. In order to support and realize this policy, the Chinese government provides financial incentives to qualified international outward investments through the loans and financial support provided by leading banks. ${ }^{44}$ Moreover, in 2007, China established a sovereign wealth fund, China Investment Corporation, specializing in investments outside China. ${ }^{45}$

On the other hand, risk forecasting and avoidance are also becoming significant features of China's outward policy. New concerns for risk avoidance appeared during the Arab spring in the first half of 2011, when Chinese enterprises and workers in Libya and other countries had to make a rapid exit at a time of heightened uncertainty and actual or potential civil conflict. In the presentation of the then presiding premier Wen Jiabao and in the course of the annual report on the work of the government (March 15, 2011), it was stated:

We will accelerate the implementation of the 'go global' strategy, improve relevant support policies, simplify examination and approval procedures, and provide assistance for qualified enterprises and individuals to invest overseas. We will encourage enterprises to operate internationally in an active yet orderly manner. We will strengthen macro guidance over overseas investments, improve the 
mechanisms for stimulating and protecting them, and guard against investment risks. ${ }^{46}$

MOFCOM coordinates such policies. ${ }^{47}$

The evolution of the Chinese strategy towards FDI as discussed above requires a balanced view, which considers both inward and outward investment. ${ }^{48}$ It has led the Chinese government to change China's IIA strategy. Moreover, understanding that investment represents only part of the commercial prospects, in order to enhance economic trade and relationships more comprehensively, China has been recently focusing on the negotiation of FTAs, rather than BITs. ${ }^{49}$ In addition, subsequent revisions of existing BITs are made. As part of this framework, the terms of the CIBIT should be revisited to adapt it to the current Chinese investment policies.

\section{B. Israel's Investment Strategy and Policy Considerations}

In the past 20 years, Israel has gained the reputation of a "start up nation" and was a recipient of many investments. However, this has to be recognized in the broader context of FDI history in Israel, in order to understand the pro-investment approach that Israeli government is leading. In the first four decades of its existence, despite continuous attempts, Israel was not successful in attracting inward FDI. This trend was due to international geopolitical factors, less developed telecommunication, road and railway infrastructure, a small domestic market, and government intervention in the economy. Most FDI were small in size and linked to solidarity of business people in the Jewish Diaspora. ${ }^{50}$ During the 1980 's, following a period of severe inflation, the Israeli government gradually discharged its interference in the economy, privatized most of the failing SOEs and introduced new liberalized policies. Since the 1990s, Israel has been implementing a thorough unilateral trade liberalization program, exposing its domestic industry to foreign competition.

Furthermore, the Israeli government is actively promoting FDI. The main lead on FDI attraction is taken by the Investment Promotion Center, the operational branch of the Ministry of Economy and Trade (formerly the Ministry of Industry and Trade and Ministry of Economy). The Investment Promotion Center's primary function is to encourage foreign investment in Israel and the cooperation between Israeli and foreign corporations. The Center has a broad network of 
local representatives operating in different countries. In China, Israel maintains five centers in order to promote investment. These centers actively co-organize investment summits and events. Moreover, the Center operates proactively, identifying potential target for Israeli companies and large foreign companies, organizing visits to Israel as well as conferences in China. The Center does not allocate its own funds for investments. ${ }^{51}$

The Ministry of Finance has the authority to provide preferential tax treatment to foreign investors under the Preferential Treatment Tax Law. These investment incentives are provided to domestic and international investors alike, and are generally allocated in accordance with the Law for the Encouragement of Capital Investment. ${ }^{52}$ This law provides geographically based incentives, diverting investment to weaker and less developed areas in the country. With the coordination of the Investments Promotion Center, foreign enterprises are provided with a wide range of incentives and benefits including grants and tax incentives.

The Office of the Chief Scientist ("OCS") in the Ministry of Economy is entrusted with execution of government policy for support of industrial R\&D ("MATIMOP"). MATIMOP offers a variety of ongoing support programs developed and offered by the OCS which play a major role in enabling Israel to be a key center for high-tech entrepreneurship, including assistance in funding to Israeli companies participating in international collaborative $\mathrm{R} \& \mathrm{D}$ programs.

Generally, in contrast to China, Israel neither regulates FDI, nor makes a separate policy, specialized corporate governance regime and separate administration that solely governs foreign investments. Israel does not have a systematic national security pre-approval review or a central governmental body responsible for preapproval or ongoing monitoring. At the same time, certain sectors, such as banking, insurance, pensions, capital markets and telecommunication are generally regulated. Investment in those sectors requires pre-approvals as part of the license term. These regulated sectors include policies that apply or restrict foreign investors through ownership restrictions or other processes to satisfy regulatory requirements. ${ }^{54}$ In addition, pre-approval may be required in cases of merger and acquisitions of monopolies, in accordance with the Israeli Anti-Monopoly Law, managed by the Israeli Anti-Trust Authority. ${ }^{55}$

Since the global economic crisis in 2007, Israel has started to shift the focus to 
its economic relations with Asia. Today, China is becoming more dominant as an economic partner, rather than depending on its traditional markets in Europe and the US. All these underlying parameters are inseparable of Israel's IIA policies. Furthermore, Israel has recently emphasized the importance of the signing of an FTA with China. Revisiting the terms of the CIBIT is clearly essential.

\section{Analysis of the Key Provisions of the CIBIT}

\section{A. General Introduction and Preamble}

The CIBIT is a concise agreement. It contains only 14 articles covering roughly 8 pages in total (Table 1).

\section{Table 1: China-Israel Bilateral Investment Treaty}

\begin{tabular}{c|l}
\hline Article & \multicolumn{1}{|c}{ Regulation } \\
\hline Pmbl. & $\begin{array}{l}\text { Recognizing that the encouragement and reciprocal protection of investments } \\
\text { on the basis of the present Agreement will be conducive to the stimulation of } \\
\text { individual business initiative and will increase prosperity in both states. }\end{array}$ \\
\hline Art.1 & $\begin{array}{l}\text { slim definition article which includes definitions only of investment, investor, } \\
\text { returns and territory }\end{array}$ \\
\hline Art. 2 & main obligation concerning promotion and protection of investments \\
\hline Art. 3 & MFN undertaking \\
\hline Arts. 4-5 & expropriation and compensation \\
\hline Art. 6 & repatriation of investments and returns \\
\hline Art. 7 & a very short passage concerning exceptions \\
\hline Art. 8 & investor - state dispute resolution \\
\hline Art. 9 & disputes between China and Israel - the Contracting Parties \\
\hline Art. 10 & subrogation \\
\hline Art. 11 & consistency and application of other rules (related to MFN provision) \\
\hline Art. 12 & application to investments \\
\hline Art. 13 & entry into force \\
\hline Art. 14 & duration and termination \\
\hline
\end{tabular}

Source: Compiled by the author. 
As discussed above, the CIBIT was ratified in 2008 in accordance with the form already agreed in the 1990s, without introducing additional changes. ${ }^{56}$ The BIT features several significant gaps, in particular those concerning its preamble, key definitions of 'Investment,' 'Investor,' FET, MFN, NT, and ISDS provisions. Such gaps might be detrimental in the future. In the event of an arising dispute, the lack of clarity may potentially lead to escalation, rather than provide for a quick resolution.

The preamble of the CIBIT focuses mainly on economic development and encouragement of investment as its underlying theme. ${ }^{57}$ Such general phrasing was common in early Chinese BITs as well as other IIAs. ${ }^{58}$ Pursuant to the Vienna Convention on the Law of Treaties ("VCLT"), the preamble constitutes a part of the immediate margin for interpretation, although it does not include binding obligations. ${ }^{59}$ Therefore, China, as well as other countries, in wake of growing ISDS, and in particular those targeting governmental actions including the Plain Packaging Act, have generally abandoned such underlying general themes. The recent approach directly refers to the governments' right to regulate the protection of public health and environment, or sustainable development as valid considerations. It is worth noting that although the CIBIT supports the "prosperity in both states," it does not clarify whether non-economic values and principles can be read in context of 'prosperity.' A detailed suggestion how this gap should be rectified will be discussed in Part IV.

\section{B. Term, Survival and Application}

The CIBIT entered into force on January 13, 2009, for a period of five years. Articles 12 and 14 of the CIBIT, however, provide it with an unlimited term of application. First, it provides retroactive application, as it applies to the rights and obligations of both Contracting Parties with respect to investments made on or before entry into force. Furthermore, a survival period of ten years is granted to investments made while the CIBIT is in force. Finally, although the basic agreement period is five years long, the agreement does not terminate automatically, but rather remains in full force and effect until either party chooses to terminate it, following a one-year notice period.

Thus, the CIBIT has, in fact, an unlimited scope of application, both retroactively and even following its termination. To date, neither of the Contracting Parties has 
submitted a termination notice. In the context of growing commercial relationship and efforts extended by both parties to strengthen the investment relationship, it seems unlikely that either of the Contracting Parties will seek to terminate it unilaterally. The combination of a non-limited term, without any limitation period for claims, opens a very broad gateway for potential claimants. Since the CIBIT does not include a clear reference for the interpretation of governing law, a question arises concerning the correlation between the limitation period under the domestic law of each country, and this unlimited scope of application. ${ }^{60}$

In the absence of an agreed choice of law, Article 42(1) of the ICSID Convention prescribes for the law of the Contracting State which is a party to the dispute, including its rules on the conflict of laws, and those of international law applies. Both international and domestic law may offer different standards of treatment and interpretation. ${ }^{62}$ Failure to apply proper law can lead to annulment of awards, under the ICSID Convention, ${ }^{63}$ or set-aside under the New York Convention. ${ }^{64}$ Thus, an ambiguity concerning the limitation period may be crucial. Such concerns are addressed in other IIAs. The China-ASEAN FTA, e.g., provides for a clear three years limitation period. ${ }^{65}$

\section{Ratione Materiae and Ratione Personae}

Ratione materiae (investment), Ratione personae (investor), Ratione temporis (time period) and Ratione volantis (consent), are all mandatory jurisdictional prerequisites. While a separate discussion is made on the key question of scope of consent to ISDS, below is a primarily examination of the definitions of the fundamental terms 'investment' and 'investor.'

As for 'investment,' the CIBIT uses an asset-based, open-ended, illustrative definition, coupled with a pertinent legality requirement. ${ }^{66}$ The definition uses several typical examples such as movable and immovable property, right derived from shares, debentures and other kinds of interests in companies, claims to money, rights in the field of IP and business concession conferred by law or under contract. ${ }^{67}$ In addition, the definition covers a change in the form of which assets are invested or reinvested. This type of definition offers a wide protection of various economic interests. It can actually apply to anything with economic value.

More importantly, the pertinent legality requirement prescribes for implementing the investment, "in accordance with the laws of the contracting party 
where the investment is made, ${ }^{, 68}$ as an integral part of the definition of investment. This feature requires investors to follow the laws where investment is made. The legality requirement has proved to be pivotal in ISDS arbitration in the past. ${ }^{69}$ It is a valve assuring that investment is made in accordance with the Contracting Parties' set of priorities and regulations. At the same time, the scope of laws and regulations included in such a requirement is not clear. In practice, it seems that every investment cannot fully comply with all laws and regulations. [Emphasis added] Naturally, at the time of crisis and dispute, investors will tend to understate the importance of such an omission. Contrarily, States will tend to overstate the importance of such violation to exclude jurisdiction. Defining either a formula or a mechanism to identify the key applicable laws pertinent to investments can abate such tensions and improve the predictability for both Contracting Parties.

Another pivotal issue related to the definition of 'investment' may arise in the context of Article 25 of the ICSID Convention and the various rulings concerning its interpretation. The ICSID Convention does not include a clear definition of the term, 'investment.' In Salini v. Moroco, however, the tribunal adopted a double key-note approach, requiring the fulfillment of four additional characteristics, namely, (1) contribution of capital, (2) duration, (3) an element of risk, and (4) contribution to a host state's economic development. ${ }^{70}$ Different arbitrators have demonstrated different approaches in the interpretation of IIAs and the ICSID convention, ranging from a double-key screening process, requiring investment, to fall under both the IIA test and the aforementioned set of characteristics, to a single screening process, focusing on the mere definition contained in the relevant IIA. ${ }^{71}$ The fragmented practice of IIAs in this regard is noticeable in Chinese IIAs as recent IIAs include a clear reference to Salini's footprints. The CIBIT should address such concerns as well.

As for the definition of 'investor,' natural person investors are nationals of the Contracting Party, pursuant to law in force in that Contracting Party, who are not nationals of the other Contracting Party, either. This definition is generally in harmony with the requirement of the ICSID Convention. ${ }^{72}$

The definition of a juridical investor, however, appears to be somewhat more complicated. The CIBIT defines "companies including corporations, firms or associations incorporated or constituted in accordance with the law of the Contracting Party concerned." ${ }^{73}$ The Protocol supplements this definition, 
prescribing that:

Companies of one Contracting Party wishing to invest in the territory of the other Contracting Party shall not be considered for the time being as investors of the first Contracting Party, if they are owned or controlled directly or indirectly by companies of the second Contracting Party. ${ }^{74}$

Clearly, this supplement was designed to deal with the establishment of 'shell corporations. ${ }^{75}$ Since the Protocol does not further define the term 'control,' or "what is the time being," it may be difficult for implementation, sometimes involving lengthy debates. ${ }^{76}$ More importantly, this exclusion does not address a denial of benefits from a juridical investor who is owned or controlled by a noncontracting party, effectively allowing 'treaty shopping' by third parties."

The ICSID Convention leaves the definition of a juridical person to the discretion of the Contracting Parties to the relevant BIT. There is an overall agreement by tribunals to rely on the classical concept of nationality based on incorporation or seat, and to refer to the IIA definition as a primary source of interpretation. Therefore, the shortcomings of the juridical investor definition should be considered. China's recent IIA strategy in this regard addresses 'treaty shopping' and 'shell corporation' by requiring "substantial business activities requirement." $"$ "

\section{Promotion and Admission of Investments, Fair and Equitable Treatment and Full Protection}

A pivotal obligation in any IIA assures foreign investors that their investment will be treated fairly in a foreign jurisdiction. Article 2 of the CIBIT includes such a threefold guarantee. The language of this article follows many IIAs that were signed in the 1980s and early 1990s. The lessons learned from increasing ISDS practice over the past ten years, requires the Contracting Parties to rethink their strategy towards such a cardinal obligation.

The CIBIT requires each of the Contracting Parties to "promote and to create favorable conditions for investments by investors of the other Contracting Party, and subject to its rights to exercise the powers conferred by its laws, to admit investments." ${ }^{79}$ This provision is designed to provide assurance to investors that each Contracting Party will encourage and create favorable conditions for 
Investment, but leaving the admission stage to the complete discretion of the host country. It is important to note that the permissible scope of the admission requirement is not clear with respect to permissible laws and regulations in the case of China. The definition of investment, as discussed above, subject investments to both "laws and regulations" (法律 and 法规 under the Chinese version). Conversely, Article 2(a) subjects the admission of investment only to laws (法律 under the Chinese version). China practices a multi-tier system of laws, with different authorities to different governmental and legislative bodies in the nexus of Chinese administration. ${ }^{80}$ Under Articles 62(3) and 67(2) of the Chinese constitution, there are 'Laws' promulgated by the National People's Congress or its Standing Committee, and 'Regulations' promulgated by the State Council or various central level ministries and bureaus. In addition, there are local laws promulgated by the different provinces, and rules adopted by local bureaus and ministries, each type of which has a different title. ${ }^{81}$ This separation and delineation of different sources of law was not clear at the time of concluding the CIBIT, because the Legislation Law of China was then still in its initial drafting stages. Therefore, even the Chinese text version cannot help to clarify this issue. This discrepancy is certainly more important on the Chinese part. By reference, the China-Canada BIT clarifies the aforementioned uncertainty by subjecting the encouragement and admittance of investments subject to Contracting Party laws, regulations and rules. ${ }^{82}$

Then, the CIBIT defines the standard of protection with the following broad terms:

Investments made by investors of each Contracting Party shall be accorded fair and equitable treatment and shall enjoy full protection and security in the territory of the contracting Party. Neither Contracting Party, shall without prejudice to its laws and regulations, in any way impair by unreasonable or discriminatory measures the management, maintenance, use, enjoyment or disposal of investments in its territory of investors of the other Contracting Party. ${ }^{83}$

Claims about violation of FET obligations predominates ISDS. ${ }^{84}$ Tribunals have provided different interpretations how to measure valve broad standards of "fair and equitable treatment" and "full protection and security." Subsequently, it is not clear which standard applies to determine whether state obligations to 
protect investment by investors are fully met. [Emphasis added] This is related to the fundamental relationship between the standards in treaty and customary international law. The formula in the CIBIT includes no reference to customary international law. This means that an arbitral tribunal must come to its own view of what is fair and equitable under the circumstances. The view of F.A. Mann is often echoed in tribunals' decisions:

\begin{abstract}
...the terms 'fair and equitable treatment' envisage conduct which goes far beyond the minimum standard and afford protection to a greater extent and according to a much more objective standard than any previously employed form of words. A Tribunal would not be concerned with a minimum, maximum or average standard. It will have to decide whether in all circumstances the conduct in issue is fair and equitable or unfair and inequitable. No standard defined by any other words is likely to be material. The terms are to be understood and implied independently and autonomously.
\end{abstract}

Both the Contracting States and the investors have thus no clear knowledge of how to fulfill FET obligations and what will be regarded as a violation of the FET standard. Moreover, the CIBIT prescribes that neither Contracting State should discriminate or impair unreasonably discriminatory measures on investors, without prejudice to the Contracting Party's right to regulate. Tribunals, however, have decided that even when a government is not acting in a discriminatory manner, i.e., providing its own nationals with the same standard of treatment, it may still be regarded in breach of FET obligations. When treatment by a state under its domestic law falls below the FET standard, non-nationals in fact become entitled to better treatment than that afforded to nationals. Thus, jurisprudence has granted investors with 'super-national' rights, independent from each host country's domestic regulations. ${ }^{86}$ Since the CIBIT does not provide any clear answer with regard to the applicable law, it leaves space for debate as to the correct interpretation and construction of the FET obligations. The Chinese approach in recent IIAs addressed these concerns by clarifying that FET is a de facto commitment for the provision of minimum standard of treatment. It is coupled with a note of interpretation specifying that the scope of such obligations is in accordance with customary international law, thereby limiting the scope of FET obligations. ${ }^{87}$ 


\section{E. Most Favoured Nation and the Missing National Treatment}

The MFN obligation is a central obligation in the context of the fragmented IIA practice. The CIBIT provides for post establishment MFN guarantee. It requires each of the Contracting Parties, neither to subject investments or returns of investors of the other Contracting Party, nor to treat them less favorably than those of any third party. ${ }^{88}$ Further, neither Contracting Party shall, in its territory, subject investors of the other Contracting Party, with regard to their management, maintenance, use, enjoyment or disposal of their investments. They are obliged not to treat them less favorable than those of any third state, either. ${ }^{89}$ Generally, MFN obligations are governed by the Ejusdem Generis principle, in that it may only apply to issues belonging to the same subject matter or the same category of subjects to which the clause relates to. ${ }^{90}$ The CIBIT does not include the "in like' formula wording, although recent Chinese IIAs do address this explicitly. ${ }^{91}$ Another pivotal issue concerns the scope of MFN commitment. The CIBIT suggests that MFN apply to the post-establishment phase only. ${ }^{92}$ Nonetheless, China has already granted the MFN pre-establishment obligations in other investment treaties.

The scope of MFN obligations have been a source of many disputes. It is difficult to find a common thread that unifies the practice of MFN. ${ }^{94}$ MFN is a pillar of the international commercial law system, whose purpose is to ensure a level playing field. Whether tribunals can establish jurisprudence through MFN provisions may be often questioned. ${ }^{95}$ There have been conflicting decisions by different tribunals in this regard, ${ }^{96}$ as well as dissenting opinions within the same tribunal. ${ }^{97}$ The ISDS provision in the CIBIT allows a narrow scope for litigation, limited to the question of appropriate compensation in the event of expropriation, pursuant to ICSID proceedings. Both Contracting Parties have already opened a broad scope for ISDS in other investment treaties, as well as to other institutions and rules, including arbitration under the UNCITRAL rules. ${ }^{98}$ The question therefore remains, whether other arbitral institutions or committees could exert jurisdiction in view of the expansive MFN provision. This is a major gap that should be addressed in a future amendment of the CIBIT.

Another related question concerns the application of MFN provisions on NT obligations. The CIBIT does not include a NT obligation. This type of IIA reflects China's policy in the 1990s and its complete avoidance of granting NT standard. ${ }^{99}$ 
This tendency should be understood in the context of China's FDI policies at the time of concluding the CIBIT, before the accession of China to the WTO. In recent years, however, China, changing its approach, is moving towards NT. The missing NT protection and the broad MFN provision may potentially lead to lengthy debates over the availability of both the protection of NT and the exact scope of such a NT guarantee. This is yet another major gap that requires the attention of the Contracting Parties.

\title{
F. Expropriation, Compensation, Necessity and Exceptions
}

An in-depth analysis of the expropriation and compensation provisions in the CIBIT in light of recent ISDS jurisprudence, further highlight the necessity of this commentary rethinking the CIBIT. The CIBIT provides for compensation in case of expropriation and losses due to armed conflict or national emergency. The expropriation provision covers both direct and indirect measures, with the following terms:

\begin{abstract}
Investments of investors of either Contracting Party shall not be nationalized, expropriated or subjected to measures having effect equivalent to nationalization or expropriation (hereinafter: 'expropriation') in the territory of the other Contracting Party, except for public purpose related to the internal needs of that Contracting Party, on a non-discriminatory basis and against reasonable compensation... The investors affected shall have a right, under the law of the Contracting Party making the expropriation, to prompt review, by a judicial or other independent authority of that Contracting Party, of his or its case and of the valuation of his or its investment... ${ }^{100}$
\end{abstract}

The language offered by the CIBIT is commonly available in many IIAs including China's. The provision requires a Contracting Party, when expropriating for the public interest, to avoid discrimination, and to provide compensation. Although the formula does not guarantee 'due process,' it does provide for redress and review that are designed to provide, de-facto, a guarantee of due-process. The CIBIT does not include any additional guidance on how to distinguish non-compensable regulation from indirect expropriation. Since virtually any regulation may have an effect on an investor's property and may reduce the financial returns from an investment, the fundamental question of a government right to regulate arises. 
The jurisprudence offers three main approaches in this respect. First, the sole effects test objectively tries to find expropriation where an investor has been substantially deprived of his/her rights, and measure the degree, duration and effects on the investor. For this discussion, the purpose of this measure is irrelevant; if there is a substantial interference with property rights, there is expropriation. Second, the 'Purpose' test would distinguish good-faith regulation from the measures that target the investor unfairly. Under such approach, the measures that enhance the general welfare would usually fall within the state's 'police powers' and not be compensable. ${ }^{101}$ Third, the balancing test approach takes into account both purpose and effect tests. This is a common formula, also adopted by China in the China-Canada BIT. ${ }^{102}$ Thus, even where there is a clearly permissible purpose, it is possible that complete annihilation of property rights would amount to a taking that requires compensation.

The balancing test is often related to proportionality test. 'Proportionality' is a fundamental principle that governs the Israeli administrative and constitutional law with clear guidelines for its application. ${ }^{103}$ It is also an agreed principle within Chinese administrative and constitutional law, although its application is not established yet. ${ }^{104}$ Finally, proportionality may be measured by international standards, since the CIBIT does not provide for a clear choice of law mechanism. As the CIBIT includes a narrow scope of purpose, any future interpretation of this provision will have to consider all such parameters. Therefore, it is advised to clarify such lacunae, as discussed below.

The Expropriation provision of the CIBIT prescribes the formula for compensation, ${ }^{105}$ similar to other IIAs. The CIBIT also provides for compensation for losses in specialized circumstances, such as war, armed conflict, revolution, state of national emergency, revolt, insurrection, riot and other similar activity and requisition or destruction of property by its forces or authorities. ${ }^{106}$ As shown in Table 2 below, these provisions lay down different formulations of compensation. The differences between the various cases would be related to the pattern of the specific case that may arise. The broad language, however, may lead to the inclusion of one fact scenario into the three different provisions. 
Table 2: Standards of Compensation in the CIBIT

\begin{tabular}{c|l|l}
\hline Articles & \multicolumn{1}{|c}{ Circumstances } & \multicolumn{1}{c}{ Standard of Compensation } \\
\hline Art. 5 & $\begin{array}{l}\text { General expropriation guarantee } \\
\text { including nationalization, expropriation } \\
\text { or equivalent measures, only for a } \\
\text { public purpose related to the internal } \\
\text { needs of that Contracting Party on a } \\
\text { non-discriminatory basis }\end{array}$ & $\begin{array}{l}\text { Reasonable compensation: } \\
\text { the market value of the investment } \\
\text { expropriated immediately before the } \\
\text { expropriation or before the impending } \\
\text { expropriation became public knowledge, } \\
\text { whichever is earlier, including interest } \\
\text { as provided by law until the date of } \\
\text { payment. }\end{array}$ \\
\hline Art. 4(1) & $\begin{array}{l}\text { War, armed conflict, revolution, } \\
\text { state of national emergency, revolt, } \\
\text { insurrection, riot and other similar } \\
\text { activity }\end{array}$ & $\begin{array}{l}\text { Compensation no less favorable than } \\
\text { that which the Contracting Party } \\
\text { accords to investors of any third party }\end{array}$ \\
\hline Art. 4(2) & $\begin{array}{l}\text { Requisition or destruction of property } \\
\text { by forces or authorities }\end{array}$ & Restitution or reasonable compensation \\
\hline
\end{tabular}

Source: Compiled by the author.

In $A D C$ v. Hungary, the BIT specified a similar expropriation provision and damage formula to the CIBIT. The tribunal in $A D C v$. Hungary, however, interpreted this provision so as to allow expropriation which covers the value of the property after the date of expropriation (in that case the value of the property increased after the expropriation). The ADC $v$. Hungary tribunal ascertained that the BIT defines damages for lawful expropriation, however, since Hungary made an unlawful expropriation, Hungary should pay additional compensation in the value of the property after the expropriation, i.e., after the value of the property increased. ${ }^{107}$ Although jurisprudence in international arbitration does not have a binding effect, the $A D C v$. Hungary decision may be considered in the future interpretation of the CIBIT as part of jurisprudence constante.

Finally, the CIBIT does not include a specialized "essential security clause" or a "non-precluded measures." Although the WTO law does not apply to investment protection, these provisions may be relevant. In Continental Casualty, the tribunal cited the WTO's reasoning concerning the doctrine of necessity and security exceptions under the WTO law. ${ }^{108}$ It seems therefore necessary to address this issue, and to follow the current trend of IIA rulemaking which is to include a 
detailed exceptions and essential security clause to expropriation. This has become a feature of Chinese recent IIA practice. ${ }^{109}$

\section{G. Investor State Dispute Resolution}

China and Israel are both signatories to the ICSID Convention. ${ }^{110}$ Article 8 of the CIBIT provides that any dispute "with respect to the amount of compensation in the case of expropriation" "111 may be submitted to the ICSID for resolution. Article 8 further requires an investor to provide written notification, with a 'cooling off' period of six months, to allow an amicable resolution of the dispute. The language provides for jurisdiction merely concerning the amount of compensation in the case of expropriation. However, if examining the ISDS provision in light of the Contracting Parties' general practice as well as general IIA jurisprudence, it gives rise to several complicated questions.

First, although Article 8 does not provide for any additional dispute settlement mechanism including the UNCITRAL Rules or the ICSID additional facility, these are commonly acceptable venues by both Contracting Parties in other IIAs. Further, both Contracting Parties are signatories of the New York Convention on the Recognition and Enforcement of Foreign Arbitral Awards of 1958 ("NYC"). Both Parties have consented to arbitration in accordance with the UNCITRAL Arbitration Rules in other IIAs and in their model BITs. There is no clear answer whether an investor can invoke proceeding under the UNCITRAL Rules, and how the PCA, e.g., as an appointing authority, should act if required to intervene.

Second, although the scope of consent stated in Article 8 of the CIBIT is specified for review of amount of compensation in the event of expropriation, the broad MFN provision discussed above may open the door to a broader type of disputes. Different tribunals have taken different approaches; some tend to open a wider door than others with regards to the MFN provision. This is a gap widely addressed in recent IIA practices. ${ }^{112}$ Such conflicting practices and approaches taken by different tribunals, certainly require us to rethink this gap.

Third, it is worth noting that the ISDS Mechanism does not require any condition precedent to the submission of a claim to arbitration. It has become common or prevalent practice in many IIAs including China's recent ones. Moreover, the ISDS does not provide for a "fork in road" provision, effectively allowing an investor to submit a dispute under both national domestic courts and international 
arbitration simultaneously. This situation may potentially lead to conflicting decisions by different tribunals and courts, in different jurisdictions at the same time. $^{113}$

Fourth, the ISDS provision does not address public access to hearings and documents, submission by a non-disputing party, and rules for transparency. Following critics in the public about the 'secret nature' of ISDS, the UNCITRAL adopted the 2014 Rules on Transparency in Investor-State Arbitration, providing a partial solution for concerns over confidentiality. ${ }^{114}$ However, the application of the Rules on Transparency presumptively will not apply to any IIAs that were enacted prior to the Rules' effective date, unless both parties to the relevant BIT agree otherwise. Therefore, a future amendment of the CIBIT should clearly address this pivotal issue, preferably adopting these Rules on Transparency.

Fifth, cardinal provisions such as the governing law and limitation period, are missing from the CIBIT, although they are often addressed as part of the ISDS section in IIAs. Governing law and limitation period are not merely procedural controversies, but have substantive implications on the basic jurisdiction question. As discussed above, the consequences of a wrongful jurisdiction decision may be detrimental, since it may lead to the annulment pursuant to the ICSID Convention, or set-aside pursuant to the NYC. The recent Chinese IIA practice addresses such concern. ${ }^{115}$ Therefore, it is highly recommended to address these issues as well in any future amendment of the CIBIT.

\section{Conclusion: Roadmap}

As of early 2016, China has concluded 129 BITs, 109 of which are in force. There are 19 regional IIAs, all of which are in force. Israel has concluded 38 BITs of which 34 are in force, and 4 of 5 IIAs are in force. ${ }^{116}$ Within this growing body of investment treaties, this paper has examined a case study of particular interest. It has discussed gaps in provisions included in a BIT negotiated in the early 1990s, but one that entered into force significantly later, in 2009. Part three has identified major gaps in the CIBIT against the underlying consideration towards investment as set out in Part two. The gaps discussed, in particular, against current Chinese IIA practice, require a thorough rethinking of the terms of the CIBIT. The short 
closing below offers a roadmap for future amendment of the CIBIT. The author would clarify that it does not intend to provide an exhaustive list of required changes to the CIBIT, but rather to point out the fundamental issues for future improvement. Specifically, this roadmap has been built on the vast experience of Chinese IIA's practices.

The first element of this roadmap is the function of the CIBIT through the lens of the sustainable development paradigm. ${ }^{117}$ China's recent IIA advocates States' right and freedom to regulate in the interest of the public good, sustainable development, protection of public health, social order and stability and the environment. ${ }^{118}$ As already discussed, the preamble of the CIBIT focuses merely on economic values. On this matter, the CIBIT neither discusses financial necessity, nor essential security interest scenarios. ${ }^{119}$

The second element of this roadmap requires rethinking of policy coherence towards standards of protection. The CIBIT uses an open-ended FET standard. However, recent IIAs rulemaking tries to define this valve standard, either including linking FET to minimum standard of treatment pursuant to international law, or by providing a definitive scope of violations with an illustrative list for such violations. ${ }^{120}$ The FET provision should be also clarified in order to enhance systematic consistency between the CIBIT and other bodies of international law. This is also extremely important in view of the broad MFN obligation included in the CIBIT because of direct connection with the missing NT protection, a legacy of the development of the FDI regime in China. ${ }^{12}$

The third element of the roadmap concerns reformulating the remedies and compensation provisions, building a more coherent standard for compensation. ${ }^{122}$ The Expropriation provision uses the Hull formula, setting out a standard of prompt, adequate and effective compensation in accordance with fair market value, which may amount to considerable sums. The Indian new draft model BIT (2015), ${ }^{123}$ e.g., uses appropriate and equitable compensation standards rather than the fair market value formula excluding consequential or exemplary losses or speculative or windfall profits claimed by the investor, including those relating to moral damages or loss of goodwill. In addition, a broad list of mitigating factors is defined. ${ }^{124}$ Subsequently, it is advised to clarify the different compensation methods available resulting from both expropriation under Article 7 of the CIBIT, and other loss scenarios listed under Article 6 of the CIBIT. The same scenario 
may be suitable for both provisions, and even entitle the investor to double compensation. This can amount to significant sums in cases of investor-state arbitration that usually involve large projects.

The fourth crucial element of the roadmap requires us to rethink the ISDS mechanism. ${ }^{125}$ The CIBIT designates the ICSID as the sole ISDS mechanism. This formula departs from the general practice of the Contracting Parties adopted in other IIAs and in their Model BITS, allowing ISDS under the UNCITRAL Rules or litigation under the relevant Party. ${ }^{126}$ As a MFN provision may be applicable to the ISDS provision, jurisdiction may be established pursuant to other rules and institutions. Thus, it is essential to clarify the permitted scope of jurisdiction under the ISDS provision (that should be made jointly with the MFN Provision) and clarification of the operation of the 'cooling off' six months period. In addition, it may be desirable to require investors to exhaust local remedies, making sure that sensitive cases are monitored prior to the commencement of international arbitration proceedings. This is particularly important in such cases as related to financial and banking industries. All such clarifications are designed to have a more orderly and smooth process with less questions about basic jurisdictional issues, allowing the disputing parties in the case to focus on its merits.

Moreover, building on current trends of IIAs practices, the whole ISDS mechanism may be reconsidered.

Departing from either the ICSID dispute resolution mechanism or the UNCITRAL dispute resolution mechanism, ${ }^{127}$ current ISDS arbitration system has attracted increasing criticism questioning its legitimacy. The opponent question whether a system founded on perception applicable to private international commercial arbitration is suitable to handle disputes with public characteristics, between states and investors. ${ }^{128}$ One approach discussed above is to resolve the shortcomings of the existing system by improving and perfecting it. The other approach offers to depart completely from the existing system. One possibility may be by departing from the ICSID system altogether by either establishing a permanent international investment tribunal between the parties, or exclusive reliance on domestic dispute resolution. Each of the alternatives is not without difficulties. $^{129}$

Finally, the fifth element of the roadmap emphasizes transparency and improves the cooperation between the Contracting Parties and additional stakeholders. With 
regard to transparency, the implementation provisions of the UNCITRAL Rules

on Transparency in Treaty-based Investor-State Arbitration, will be a milestone, ${ }^{130}$ because they clarify key aspects such as public access to hearings and documents, as well as the role of stakeholders that are non-disputing parties (amicus curiae).

\section{REFERENCES}

1. M. Sornarajah, The international Law on Foreign inVestment 257-62 (3d ed. 2010).

2. UnCTAD, The Impact of International Investment Agreements on Foreign Direct Investment: An Overview of Empirical Studies 1998-2014 (IIA Issues Note on Sept. 2014 Working Draft), available at http://investmentpolicyhub.unctad.org/Upload/Documents/ unctad-web-diae-pcb-2014-Sep\%2024.pdf (last visited on Aug. 10, 2016).

3. An CHEN, The voice from China: An CHEN on International Economic Law 314 (2014).

4. H. Milner, Introduction: The Global Economy, FDI, and the Regime for Investment, 66 World Politics 1-11 (2014).

5. ICSID, The ICSID Caseload-Statistics, Issue: 2016-2, available at https://icsid.worldbank. org/apps/ICSIDWEB/resources/Pages/ICSID-Caseload-Statistics.aspx. See also Record number of Investor-State Arbitrations filed in 2015, available at http://investmentpolicyhub. unctad.org/News/Hub/Home/460 (all last visited on Aug. 10, 2016). (Tendency remains high in the first half of 2016); UNCTAD, World Investment Report 2015: Reforming International Investment Governance (hereinafter WIR 2015), at 123. (During the years 1990-2007 a total of 2,663 new IIAs were concluded. At the same time a new phenomenon in IIA world had become apparent. Until 1990, only a single case of ISDS was reported, but in the period between 1990 and 2007, a total of 291 cases were reported. The global economic crisis heavily influenced the practice of IIA. From 2008 to 2015, a total of new 410 IIAs were concluded and 316 new ISDS cases were reported.)

6. For details on ISDS Corporate Attacks Organization criticism about Phillip Morris vs. Australia, see ISDS Corporate Attacks Organization, Isds-attacks, available at http://www. isdscorporateattacks.org/\#!health/cqb (last visited on Aug. 10, 2016).

7. Id.

8. A. Reinisch, Necessity in International Investment Arbitration - An Unnecessary Split of Opinions in Recent ICSID Cases: Comments on CMS v. Argentine and LG\&E v. Argentine, 8 J. World Inv. \& Trade 195 (2007), available at http://heinonline.org/HOL/Landing Page?handle=hein.journals/jworldit $8 \&$ div=13\&id=\&page=; F. Frank, The Legitimacy Crisis in Investment Treaty Arbitration: Privatizing Public International Law through Inconsistent Decisions, 73 Fordham L. Rev. $1582-7$ (2005), available at http://papers.ssrn.com/sol3/ papers.cfm?abstract_id=812964 (all last visited on Aug. 10, 2016). Argentina represents a 
clear example of such risks. When Argentina took financial measures in wake of a financial crisis, these measures were disputed by investors that submitted their claims invoking international obligations pursuant to Argentina' IIAs. Different arbitral panels came to different conclusions while balancing claims given rise by similar financial measures.

9. Agreement between the Government of Canada and the Government of the People's Republic of China for the Promotion and Reciprocal Protection of Investments (2012), Oct. 1, 2014 (hereinafter China-Canada BIT), available at http://investmentpolicyhub.unctad.org/IIA/ treaty/778 (last visited on Aug. 10, 2016).

10. Free Trade Agreement between the Government of Australia and the Government of the People's Republic of China (2015), Dec. 20, 2015 (hereinafter China-Australia FTA), available at http://investmentpolicyhub.unctad.org/IIA/country/42/treaty/3572 (last visited on Aug. 10, 2016).

11. J. Chaisse, TPP Agreement: towards Innovation in Investment Rule-Making, in THE TRANSPacific Partnership: A Quest for a Twenty-first Century Trade 147-54 (C. L. Lim et al. eds., 2012).

12. PMK Robin, Bit Won't Bite: The American Bilateral Investment Treaty Program, 33 Ам. U. L. Rev. 931 (1983-1984), available at http://heinonline.org/HOL/LandingPage?handle=hein. journals/aulr33\&div=43\&id=\&page= See also E. Zachary et al., Competing for capital: The diffusion of bilateral investment treaties, 1960-2000, 60 InT'L ORG. 811-46 (2006), available at https://dash.harvard.edu/bitstream/handle/1/3017499/Simmons_CompetingFor. pdf? sequence=2 (all last visited on Aug. 10, 2016).

13. WIR 2015, supra note 5.

14. Agreement on Investment of the Framework Agreement on Comprehensive Economic Cooperation between the People's Republic of China and the Association of Southeast Asian Nations (hereinafter China-ASEAN Framework Agreement). For details, see Hucheng Gao, Successful Signing of the China-ASEAN FTA Upgrading Protocol, XinHuanet, Dec. 2, 2015, available at http://fta.mofcom.gov.cn/enarticle/chinadmen/endmnews/201512/29597_1. html (last visited on Aug. 10, 2016).

15. Agreement between the Government of People's Republic of China and the State of Israel for the Promotion and Reciprocal Protection of Investments (2009), available at http://tfs. mofcom.gov.cn/aarticle/h/at/201002/20100206778904.html (last visited on Aug. 9, 2016).

16. Y. Evron, Foreign Relations: China Israel Relations in Retrospect: Obstacles, Success and Future Trend [Yachasei Chutz: Yachasei Sin Israel Bemabat Leahor: Michsholim, Haztlachot VeKivunim Efsharim] 18 Yinuim BetKumut IsRael 243-6 (2008) <available only in Hebrew>

17. J. Shahevet, Using Science as means for Advancing Diplomacy, China and Israel [Hamad Besherut Hadiplomatia: China and Israel] (2009). < available only in Hebrew>

18. A. Shay, Sino-Israeli Relations: Current Reality and Future Prospects; Memorandum, No. 100 (Institute for National Security Studies, 2009). 
19. Supra note 3, at 100.

20. Supra note 16, at 248.

21. IMF, Israel: Financial System Stability Assessment, IMF Country Report No. 12/69, (April, 2012), available at https:/www.imf.org/external/pubs/ft/scr/2012/cr1269.pdf; China: Economic Outlook, IMF Country Report (Feb. 2012), available at https://www.imf.org/ external/country/CHN/rr/2012/020612.pdf (all last visited on Aug. 10, 2016).

22. See OECD FDI regulatory Restrictiveness Index, available at http://stats.oecd.org/Index. aspx?datasetcode=FDIINDEX\# (last visited on Aug. 10, 2016).

23. Supra note 3, at 85-8.

24. Id.

25. M. Endicott, China and International Investment Law: An Evolving Relationship, in Silk Road Studies in International Economic Law, vol. 1: China and International InVESTMENT Law: Twenty Years of ICSID Membership 215-34 (Wenhua Shan \& Jinyuan Su eds., 2014). See also V. Bath, Chinese Companies and Outbound Investment: The Balance between Domestic and International Concerns, in China IN the International Economic Order: New Directions and Changing Paradigms 227-44 (L. Toohey et al. eds., 2015); Yongjie LI, Factors to be Considered for China's Future Investment Treaties, in SHan \& Su, id. at 174-9.

26. T. Mahony, Foreign Investment Law in China: Regulation, Practice and Context 4-12 (2015).

27. People's Republic of China Law Income Tax for Foreign Invested Enterprises and Foreign Enterprises [中华人民共和国外商投资企业和外国企业所得税法]. (The regime allowed a corporate income tax rate of $15 \%$, two years exemption for the first two making profit years and three years half exemption for the next following three years. In contrast, at the same time, Chinese enterprises corporate tax rate was of $30 \%$ ).

28. Circular Concerning Issues Related to Foreign Investment in the Establishment of Research and Development Centers, [外经贸部关于外商投资设立研究发中心有关问题的通知], issued by the Ministry of Foreign Trade and Economic Cooperation on April 18, 2000 .

29. The Enterprise Income Tax Law of the PRC [中华人共和国企业所得税法], promulgated by the Fifth Session of the Tenth National People's Congress on March 16, 2007 and effective from January 1, 2008.

30. E.g., Beijing attracts foreign investment with additional tax incentives, available at http:// beijing.china.org.cn/2012-12/18/content_27446341.htm (last visited on Aug. 10, 2016).

See also Tianjin attracts business in the Free Trade Zone: Regulations of the Tianjin Harbour Free Trade Zone on Preferential Tax Treatment [天津市税务局关于天津港保税区税 收优恵的若干规定].

31. Supra note 26, at 118-50. (It provides an overall detailed explanation of the different ministries and their roles in approving foreign investment).

32. People's Republic of China Sino-Foreign Equity Joint Venture Law [中华人民共和国中外合 
资经业法], promulgated by the 2nd Session of the 5th National People's Congress on July 1, 1979 This law in fact preceded the economic reforms in China.

33. People's Republic of China Sino-Foreign Cooperative Joint Venture Law [中华人民共和国中 外合作经营企业法], promulgated by the 1st Session of the 7th National People's Congress on April 13, 1988.

34. People's Republic of China Law on Wholly Foreign Owned Enterprises [中华人民共和国中 外资企业法], promulgated by the 4th Session of the 6th National People's Congress on April 12, 1986.

35. Provisional Regulations on Certain Questions Related to the Establishment of Foreign Funded Joint Stock Companies Limited [关于设立外商投资股份有限公司若干问题的执行规定], promulgated by the Ministry of Foreign Trade and Economic Cooperation on January 10, 1995

36. Hui Huang, The Regulation of Foreign Investment in Post-WTO China: A Political Economy Analysis, 23 Colum. J. Asian L. 185 (2009-2010), available at http://heinonline.org/HOL/ LandingPage?handle=hein.journals/colas $23 \& \operatorname{div}=10 \& i d=\&$ page $=$ (last visited on Aug. 10, 2016).

37. Notice of the Ministry of Commerce on Soliciting Public Opinions on the Foreign Investment Law of the People's Republic of China (Draft for Comments) [商务部就 中华人 民共和国外国投资法(草案征求意见稿)公开征求意见]. (“The MOFCOM is of the opinion that the Foreign Investment Law shall position itself as a law that serves to deepen institutional reform, expand liberalization, promote foreign investment and regulate foreign investment management. With the aim of unifying laws and regulations on domestic and foreign investment...") See Draft Foreign Investment Law, art. 1.

38. The Anti-Monopoly Law of the People's Republic of China, adopted at the 29th meeting of the Standing Committee of the Tenth National People's Congress of the People's Republic of China on August 30, 2007. (The Anti-Monopoly Law was preceded by specialized M\&A regulations applicable to foreign M\&A).

39. D. Healey, Mergers with Conditions in China: Caution, Control or Industrial Policy, in Toohey et al., supra note 25 at 245-67. See also Shaun Rein, What Coca-Cola Did Wrong, and Right, in China, ForBes, Mar. 24, 2009, available at http://www.forbes.com/2009/03/24/ coca-cola-china-leadership-citizenship-huiyuan.html (The Coca Cola Hui Yuan Case nonapproval of the merger and acquisition is an example); D. Harris, China Rejects Coke Deal. We Told You All This Long Ago, China Law Blog, Mar. 18, 2009, available at http://www. chinalawblog.com/2009/03/china_rejects_coke_deal_we_tol.html (last visited on Aug. 10, 2016).

40. Draft Foreign Investment Law ch. 4

41. Id. See also Notice of the General Office of the State Council on Printing and Distributing Trial Measures for the National Security Review of Foreign Investment in Pilot Free Trade Zones, promulgated by the General Office of the State Council on Aug. 4, 2015 [国务院办公 
厅关于印发自由贸易试验区外商投资过家安全审查试行办法的通知].

42. Supra note 36.

43. Yuan Gao, 'One Belt One Road' offers many opportunities, China Daily, Mar. 7, 2015, http://www.chinadaily.com.cn/business/2015-03/27/content_19925552.htm (last visited on Aug. 10, 2016).

44. China Export-Import Bank (EXIM Bank), Annual Report, available at http://english. eximbank.gov.cn/tm/en-PDF/index.aspx?nodeid=634\&pdf=20156/20156911264314532. pdf. The 2015 China-Exim Bank Annual Report list the major projects of the bank finances, including acquisition of a mine in Peru. See also China Development Bank, News, available at http://www.cdb.com.cn/english/NewsInfo.asp?NewsId=742 (all last visited on Aug. 10, 2016). (China Development Bank actively promote 'go-globalization' program, to support the globalization program of private and state owned companies in China).

45. See CIC Capital Joined a Consortium to Acquire 65\% Equity Interests in Kumport [Turkey], China Investment Corporation News, Dec. 10, 2015.

46. State Information Office, Report on the Work of the Government, delivered at the 4th Session of the 11th National People's Congress on March 5, 2011, available at http://www. gov.cn/english/official/2011-03/15/content_1825268.html (last visited on Aug. 10, 2016).

47. For details on practical advice for investors in various countries, and in particular about Israel see MOFCOM's FDI website, available at http://english.mofcom.gov.cn/departments/ hzs2 (last visited on Aug. 10, 2016).

48. LI, supra note 25.

49. MOFCOM, China's FTA Plan, available at http://fta.mofcom.gov.cn/topic/enkorea.shtml (last visited on Aug. 10, 2016).

50. Yair Aharoni, Inward FDI in Israel and its Policy Context, in Columbia FDI Profiles, Jan. 31, 2011 (Yale-Columbia Ctr. on Sustainable International Investment), available at http:// ccsi.columbia.edu/files/2014/03/Israel_IFDI_Jan_31_11_0.pdf (last visited on Aug. 10, 2016).

51. F or details, see Ministry of Economy and Industry, available at http://www.investinisrael. gov.il/index.html (last visited on Aug. 10, 2016).

52. Ministry of Finance, A Committee for monitoring benefits pursuant to investment promotion law [Zevet Bedika Leyinayan Hahok Leyidud Haskaot On] <available only in Hebrew>, available at $\mathrm{http} / /$ mof.gov.il/Committees/Pages/BenefitsCommittee.aspx (last visited on Aug. 10, 2016).

53. For details, see Israeli Industry Center for R \& D, available at http://www.matimop.org.il (last visited on Aug. 10, 2016).

54. H. Geron, 'Contemporary and Future Trend in Licensing - The Israeli Case, Presentation (Sept. 13, 2012), available at http://www.moc.gov.il/sip_storage/FILES/0 (last visited on Aug. 10, 2016).

55. For details, see The Antitrust Authority, available at http://www.antitrust.gov.il/eng/default. 
aspx (last visited on Aug. 10, 2016).

56. China-Canada BIT (2012).

57. CIBIT, pmbl. (It reads: "Desiring to intensify the economic cooperation of both States on the basis of equality and mutual benefits; Intending to create favorable conditions for greater investments by investor of either Contracting Party in the territory of the other Contracting Party; and Recognizing that the encouragement and reciprocal protection of investment on the basis of the present agreement will be conducive to the stimulation of individual business initiative and will increase prosperity in both states").

58. International Investment Agreement Negotiations Handbook APEC/UNCTAD Modules, CTI 15 10T CR (2012), available at http://investmentpolicyhub.unctad.org/Upload/ Documents/UNCTAD_APEC\%20Handbook.pdf (last visited on Aug. 10, 2016). See also Colombia-Japan BIT (2011).

59. VCLT arts. $31 \& 32$.

60. T. Begic, Applicable Law in International Investment Disputes 25-56 (2005). See also W. M. Reisman \& M. Arsanjani, Applicable Law under ICSID Convention: The Tortured History of the Interpretation of Article 42, in Building International InVESTMEnt Law: The First 50 Years of ICSID (M. Kinnear et al. eds., 2015).

61. 1965 Convention on the Settlement of Investment Disputes between States and Nationals of Other States, 575 U.N.T.S. 159; 4 I.L.M. 532 (1965) (hereinafter ICSID Convention), art. 42.

62. C. Schreuer, The ICSID CONVEntion: A COMmentary 545-636 (2009).

63. ICSID Convention art. 53.

64. Convention on the Recognition and Enforcement of Foreign Arbitral Awards of 1958, 330 U.N.T.S. 38; 21 U.S.T. 2517; 7 I.L.M. 1046 (1968) (hereinafter New York Convention), art. $\mathrm{V}$.

65. China-ASEAN Framework Agreement, art. 14(6)

66. CIBIT art. 1(1)

67. Id.

68. Id.

69. Fraport AG Frankfurt Airport Services Worldwide v Philippines, ICSID Case No. ARB/03/25, Aug. 16, 2007, available at http://www.italaw.com/cases/456 (last visited on Aug. 10, 2016). See also J. Kalicki et al., Legality of Investment, in Kinnear, supra note 60, at $127-42$.

70. Salini Costruttori S.p.A. and Italstrade S.p.A. v. Kingdom of Morocco, ICSID Case No. $\mathrm{ARB} / 00 / 4$, available at https://icsid.worldbank.org/apps/ICSIDWEB/cases/Pages/casedetail. aspx? CaseNo=ARB/00/4 (last visited on Aug. 10, 2016).

71. E. Gaillard \& Y. Banifatemi, The Long March towards Jurisprudence Constante on the Notion of Investment, in Kinnear, supra note 60, at 97-126.

72. C. Schreuer, Criteria to Determine Investor Nationality (Natural Persons), in Kinnear, supra 
note 60 , at $153-62$.

73. CIBIT art. 1(3).

74. CIBIT Protocol, art. 1, ๆ 3(b).

75. Tokios Tokele 's v. Ukraine, ICSID Case No. ARB/02/18, available at https://icsid. worldbank.org/ICSID/FrontServlet?requestType=CasesRH\&actionVal=showDoc\&docId= DC2232_En\&caseId=C220 (last visited on Aug. 10, 2016).

76. P. Tercier \& Nhu-Hoang Tran Thang, Criteria to Determine Investor Nationality (Juridical Persons), in Kinnear, supra note 60, at 141-52.

77. S. Jagusch et al., Restructuring Investments to Achieve Investment Treaty Protection, in Kinnear, supra note 60, at 175-90.

78. China-Canada BIT art. 16.

79. CIBIT art. 2.

80. Albert H.Y. Chen, A Brief Introduction to the Legal System of the People’s Republic of CHINA ch. 6 (2011).

81. The Legislation Law of the People's Republic of China, adopted by the 3rd Session of the 9th National People's Congress on March 15, 2000.

82. China-Canada BIT, ๆ D. 34. 2.

83. CIBIT art. 2(2).

84. F. Marshall, Issues in International Investment Law Background Papers for the Developing Country Investment Negotiators' Forum 1-19 (2007), available at https:// www.iisd.org/pdf/2007/inv_fair_treatment.pdf(last visited on Aug. 10, 2016).

85. F. Mann, British Treaties for the Promotion and Protection of Investments, 52 BRIT. Y.B. InT'L L. 244 (1981). See also S. Vascianne, The Fair and Equitable Treatment Standard in International Investment Law and Practice, 70 BRIT. Y.B. INT'L L. 144 (1999).

86. CME Czech Republic B.V., Partial Award, Sept. 13, 2001, ๆ 611, available at http://www. italaw.com/sites/default/files/case-documents/ita0178.pdf. See also SD Myers Inc. v. The Government of Canada, Partial Award, Nov. 13, 2000, - 263, available at http://www. italaw.com/sites/default/files/case-documents/ita0747.pdf; Petrobart Limited v. The Kyrgyz Republic, SCC Case No. 126/2003, Arbitral Award, Mar. 29, 2005, ๆ 26, available at http:// www.italaw.com/sites/default/files/case-documents/ita0628.pdf (all last visited on Aug. 10, 2016).

87. Free Trade Agreement between the Government of the People's Republic of China and the Government of Korea (2015), art. 12.5.

88. CIBIT art. 3.

89. Id.

90. UnCtad, Most Favoured-Nation Treatment: II UnCtad Series on Issues in International Agreements 21-37 (2010), available at http://unctad.org/en/Docs/ diaeia20101_en.pdf(last visited on Aug. 10, 2016).

91. Agreement among the Government of Japan, the Government of the Republic of Korea 
and the Government of the People's Republic of China for the Promotion, Facilitation and Protection of Investment (2012) (JKC Trilateral Investment Agreement), art. 4(1), available at http://investmentpolicyhub.unctad.org/IIA/treaty/3302 (last visited on Aug. 10, 2016). See also China-Canada BIT (2012) art. 5.

92. CIBIT art. 3.

93. China-Canada BIT(2012) art. 5.

94. M. Kinnear, A Further Update on Most-Favored-Nation Treatment - In Search of a Constant Jurisprudence, in Contemporary Issues in International Arbitration and Mediation (A. Rovine ed., 2010).

95. E. Gaillard, Establishing Jurisdiction through a Most Favored Nation Clause, 233 N.Y.L.J. (2005), available at http://www.shearman.com/ /media/Files/NewsInsights/ Publications/2005/06/Establishing-Jurisdiction-Through-a-MostFavoredN__Files/ Download-PDF-Establishing-Jurisdiction-Through-a_/FileAttachment/IA_060205.pdf (last visited on Aug. 10, 2016).

96. Tza Yap Shun v. Peru, ICSID Case No. ARB/07/6, Decision, ๆ 96 (Feb. 12, 2015), available at http://www.italaw.com/sites/default/files/case-documents/italaw4371.pdf (last visited on Aug. 10, 2016).

97. Impregilo S.p.A. v. Argentine Republic, ICSID Case No. ARB/07/17, Prof. Brigitte Stern's Concurring \& Dissenting Opinion (June 21, 2016), available at http://arbitration.org/sites/ default/files/awards/arbr-2011-98-2.pdf (last visited on Aug. 10, 2016).

98. China-Canada BIT art. 22.

99. Wenhua Shan et al., National Treatment for Foreign Investment in China: A Changing Landscape, 27 ICSID REv. 120-44 (2012), available at http://icsidreview.oxfordjournals. org/content/27/1.toc (last visited on Aug. 10, 2016).

100. CIBIT art. 5.

101. L. Fortier \& S. Drymer, Indirect Expropriation in the Law of International Investment: I know it when it See it, 19 ICSID Rev. 313-19 (2004), available at http://icsidreview. oxfordjournals.org/content/19/2/293. extract (last visited on Aug. 10, 2016).

102. China-Canada BIT, Annex B-10.

103. CA 6821/93 Bank Mizrahi v. Migdal Cooperative Village [1995] ISRsc 49(4) 221 (trans. into Eng. in [1995] ISRLR).

104. Xuexian Huang, Study on the Principle of Proportionality of Administration Law [行政法中 的比例原则研究] <available only in Chinese>, 1 SCIENCE OF LAW [法律科学] 72-8 (2001).

105. CIBIT art. 5.

106. Id. art. 4.

107. ADC v. Hungary, ICSID Case No. ARB/03/16, Award (Oct. 3, 2006), available at http:// www.italaw.com/documents/ADCvHungaryAward.pdf (last visited on Aug. 10, 206). For details, see John Y, Gotanda, Assessing Damages: Valuation Standards, in Kinnear, supra note 60 , at $523-2$. 
108. Cont'l Cas. co. v. Arg. Republic, ICSID Case No. ARB/03/9, Award, 192 (Sept. 5, 2008), available at http://www.italaw.com/documents/ContinentalCasualtyAward.pdf (last visited on Aug. 10, 2016). The "doctrine of necessity" under customary international law may still be available GATT

109. China-Korea FTA art. 12.14; China-Canada BIT art. 33

110. China signed the ICSID Convention on February 9, 1990, ratified on January 6, 1993 and became a member on February 6, 1993. Israel signed the ICSID Convention on June 16, 1980, ratified it on June 22, 1983, and became a member on July 22, 1982. See ICSID, Signatory and Contracting States, available at https://icsid.worldbank.org/apps/ ICSIDWEB/about/Pages/Database-of-Member-States.bak.aspx?tab=FtoJ\&rdo=BOTH (last visited on Aug. 10, 2016).

111. CIBIT art. 8. [Emphasis added]

112. China-Korea FTA art. 12.4.3.

113. China-Canada BIT (2012) art. 21(2)d.

114. UNCITRAL Arbitration Rules on Transparency in Treaty Based Investor-State Arbitration, available at http://www.uncitral.org/uncitral/en/uncitral_texts/arbitration/ 2014Transparency.html (last visited on Aug. 10, 2016). See S. Levander, Resolving "Dynamic Interpretation": An Empirical Analysis of the UNCITRAL Rules on Transparency, 52 Colum. J. Transnat'L L. 506-41 (2014), available at http://jtl.columbia.edu/wp-content/ uploads/sites/4/2014/05/52ColumJTransnatlL506_Resolving-Dynamic-Interpretation_AnEmpirical-Analysis-of-the-UNCITRAL-Rules-on-Transparency.pdf (last visited on Aug. 10, 2016).

115. China-Canada BIT (2012) art. 21(2)f.

116. UNCTAD, Investment Policy Hub, available at http://investmentpolicyhub.unctad.org/IIA/ IiasByCountry\#iiaInnerMenu (last visited on Aug. 10, 2016).

117. WIR 2015, supra note 5, at 125-30.

118. E.g., China-Japan-Korea Triparty Investment Agreement, pmbl. \9ा 3-5.

119. China-Canada BIT (2012) art. 33

120. WIR 2015, supra note 5, at 137-40.

121. Wenhua Shan \& N. Gallagher, China, in Commentaries on Selected Model Investment Treaties ch. 4 (C. Brown ed., 2013).

122. WIR 2015, supra note 5, at 144-5.

123. Indian Model BIT art. 5.6-5.7, available at https://mygov.in/sites/default/files/master image/Model\%20Text\%20for\%20the\%20Indian\%20Bilateral\%20Investment $\% 20$ Treaty. pdf (last visited on Aug. 10, 2016).

124. Id.

125. CIBIT art. 5.

126. China-Canada BIT (2014) art. 22; Israel-Columbia FTA art. 10.12(3).

127. WIR 2015, supra note 5, at 145-55. 
128. See Investor-State Dispute Settlement: The Arbitration Game, Economist, Oct. 11, 2014, available at http://www.economist.com/news/finance-and-economics/21623756governments-are-souring-treaties-protect-foreign-investors-arbitration. See also UNCTAD, Reform of Investment State Dispute Settlement: In Search of A Roadmap (Issue Note on June 26, 2013), available at http://unctad.org/en/PublicationsLibrary/webdiaepcb2013d4_ en.pdf (all last visited on Aug. 10, 2016).

129. WIR 2015, supra note 5, at 145-55.

130. Levander, supra note 117. See also T. Landau \& J. Weermantry, A Case for Transparency in Investment Arbitration, in Kinnear, supra note 60, at 669-84. 